\title{
ON THE EARLIEST SLAVIC BORROWINGS IN EAST BALTIC
}

\author{
Rick DERKSEN \\ Leiden
}

\section{Introduction}

Both Lithuanian and Latvian have borrowed extensively from Slavic. A close study of the evidence allows us to distinguish several layers of borrowing. Pioneering work in this field was done by Endzelinns (1899) for Latvian and by Būga for Lithuanian (1912a, 1912b, 1925). By then Brückner's characteristically biased study of the Slavic borrowings in Lithuanian (1877) had already become outdated (cf. the introduction of Skardžius 1931). In this article the main focus will be on the earliest Slavic borrowings in East Baltic, ${ }^{1}$ that is to say those early borrowings that can be distinguished from inherited lexical items by formal criteria. ${ }^{2}$ We shall investigate what these words can tell us about the development of the East Baltic languages as well as what they reveal about the donor language (cf. Levin 1972: 149).

\section{Phonology}

Starting from the Slavic originals, we may select a number of phonemes and sequences of phonemes whose reflexes in East Baltic borrowings are of particular interest. In this section we shall attempt to establish these sound substitutions. The relative chronology that underlies them will be discussed in section 3 .

\subsection{PSl. *CorC, *CerC ${ }^{3}$}

East Baltic borrowings from East Slavic ${ }^{4}$ usually reflect polnoglasie, e.g. Lith. karãlius 'king', gãradas (Lz., Zt.) 'town', mãlatas (Lz., Zt.) 'hammer',

1 Important sources for the data mentioned in this article, in particular with respect to accentuation, were ME and EH for Latvian and the LKŽ for Lithuanian.

2 It is widely recognized that the oldest Slavic borrowings in Baltic and vice versa cannot be distinguished from inherited words on purely formal grounds (cf. Eckert 1973: 59; Robinson 1973: 127).

3 The Proto-Slavic sounds in the titles of the subsections contain no prosodic information and represent a traditional Common Slavic sound system.

4 I shall refrain from identifying the donor language as Proto-East Slavic, "Ruthenian", ProtoRussian, (Old) Russian, or Belarusian unless it is vital to the point that I am trying to make. In general the donor language is represented by examples from Russian. 
seredà (OLith., dial.) 'Wednesday', žereba (Ds.) 'lot', Latv. garadskàis (Klp.) 'towndweller', čaravât (Klp.) 'practice witchcraft'. There are a few Latvian forms, however, that seem to predate this East Slavic development, viz. Latv. kal̃ps 'servant, farm hand', kārms (Latg.) 'building', žer̃ bingš [er̃, èr $\left.r^{2}\right]$ 'lot', ${ }^{5}$ cf. Ru. xolóp 'villein, serf', xorómy 'big wooden house', žérebej 'piece, cut'. In Finnish, too, we find forms that reflect the original sequence, e.g. palttina 'linen', varpunen 'sparrow', värttinä 'distaff', cf. Ru. polotnó, vorobéj, veretenó 'spindle'. The question is if there are also Lithuanian forms of this type.

Būga (1925: 29, 35) claims that čérpe 1 (also čer̃è 2, čerpẽ 4) 'tile, clay dish', skavardà 3 (dial.) 'frying pan', karvõjus 'large wedding cake', and kar̃bas 4 (OLith., dial.) 'basket', cf. Ru. čerepók 'broken piece of pottery', skovorodá 'frying pan', korováj (also spelled karaváj) 'cottage loaf', kórob 'box, basket', were borrowed prior to the rise of polnoglasie. Bjørnflaten (2006: 66), referring to Zinkevičius (1998: 63-64), simply states that in all these cases there are alternative explanations, concluding that in Lithuanian, unlike in Latvian and Finnish, there are no examples. Zinkevičius' formulation (1987: 21; l.c.) turns out to be more cautious, however. The main idea is that we may be dealing with syncopated reflexes of polnoglasie, but to my mind the existence of the doublets čerpyčia / čerepyčia 'tile', skavardà / skavarada, karavõjus / karavõjus, and kar̃bas / karãbas does not necessarily mean that the shorter forms are secondary. The same word may have been borrowed at different stages and in different areas. In view of OPl. korb and MHG korp, Lith. kar̃bas may not be of East Slavic origin at all. That does not hold good for karbijà / karabijà, which cannot be separated from Ru. korob'já < *korbbja.

Conspicuously absent from the discussion in the above-mentioned publications is the form kálpas 1 'servant, farmhand', which occurs in the works of Daukantas. In a manuscript that was published long after his death (1959: 579), Būga says that kálpas is a borrowing from Latvian. Both Fraenkel (LEW: 210) and Smoczyński (2018: 476) do not mention this possibility and regard kálpas as an authentic Žemaitian word. In view of such forms as the synonymous kálpa (Valančius, Daukantas), kalpýnas (Kretinga area) 'good-for-nothing', and kalpáuti (Lnkv.) 'be a servant', I see no reason to assume that Latvian served as an intermediary. Equally unnecessary seems

5 Alongside žerbinus mest 'cast lots' we find žerebinus mest (Golg., Mar., Sessw.). It is remarkable that all dialect forms mentioned in ME (IV: 804) show no lengthening before tautosyllabic $r$ (only a dictionary from 1879 has žêrbinšs). This may point to a recent borrowing (cf. Endzelin 1922: 102-103), which would be incompatible with an archaic structure of the root. 
the assumption that kálpas originates from *kalapas, which Fraenkel presents as a possibility and Smoczyński as the best option.

Another etymon that may have been borrowed from East Slavic before the rise of polnoglasie is Lith. šálmas 3 [3/4] 'helmet' (thus LEW: 960; ALEW: 1008). Būga does not mention this form in his articles on Slavic borrowings, but elsewhere (e.g. 1922: 68) he has correctly argued that šálmas was not borrowed directly from Germanic but through Slavic. The Slavic forms, e.g. ORu. šelomb, Ru. (dial.) šelóm, šolóm, Ukr. šolóm, Pl. szłom, Sln. šlẹm, point to * šelmb (a) (cf. Pronk-Tiethoff 2013: 95), while the Germanic etymon is *helmaz, e.g. OHG helm, which is usually derived from PIE *kel- 'hide, cover' (cf. Kroonen 2013: 219). If we were to assume that the Baltic forms are inherited, the acute lacks an explanation, but this would also be true in the case of a borrowing. An attempt at an explanation is found in Pronk-Tiethoff's monograph (2013: 264-273, with references to alternative views), where it is argued that masculine $o$-stems with a heavy syllabic nucleus deriving from Germanic masculine words joined AP (a) because in masculine $o$-stems with a non-acute root accentual mobility had been generalized and it was unusual for Germanic borrowings to join AP (c). Since the Lithuanian forms derive from * šlmb rather than *šelmb, I assume that in East Slavic, where ${ }^{*} \mathrm{CelC}$ yields $C o l o C,{ }^{6}$ the $* e$ had become labialized under the influence of the $* l$ before polnoglasie occurred (cf. Shevelov 1964: 404), possibly after the rise of the new timbre distinctions. It is precisely in view of Lith. šálmas that Holzer (2001: 42) claims that the "North Slavic" development * CelC > $\mathrm{CalC}$ preceded * $a>o$, but the substitution of Baltic $a$ for Slavic $o$ can be shown to have been regular for a long period (cf. Levin: 2003: 143 and see section 4.4.). Finally, the fact that the Lithuanian word is mobile need not worry us in view of the spread of accentual mobility.

\subsection{PSI. *e, *o}

Early borrowings from East Slavic have $\dot{e}$ in Lithuanian and $\bar{e}$ in Latvian where the donor language had a reflex of *e, e.g. Lith. mètà 2 [1/2/4] 'mint', svễtastis (OLith.) 'sacrament, relic', préslas 3 [2/3] 'stack of grain or hay', Latv. mệtra 'mint', svętts 'holy', grẹ̀da 'pile, heap, flower bed', mètelis 'cloak'. This is an indication that ${ }^{*} e$ had already been denasalized and that the East Slavic reflex was probably * $x$;, which later became $a$ with palatalization of a preceding consonant, cf. Ru. mjáta, svjátost' 'sanctity', prjáslo, grjadá,

6 After palatal consonants we also find $e l o C$, as shown by the examples. 
ORu. mjatelb. The same vowels are substituted for $* a<* a,{ }^{*}$ after palatal consonants (Slavic $*^{*}$, $\left.{ }^{*}{ }^{\prime}, * z\right)$ ) and $j$. In Latvian, we actually find $\bar{e}$ for $* \check{e}$ in general (see 2.5.). In Lithuanian, we occasionally encounter doublets with $o$ in this environment, e.g. čếbras and čiôbras 'summer savory'. According to Būga (1912a: 10), forms with $\dot{e}$ are older, but Levin (2003: 141) questions this, considering that the sequence $* j x$ : was phonologically ambiguous.

In the case of East Slavic borrowings containing a reflex of PSl. * $q$, several old borrowings appear to have $u o$ in Latvian, but $\bar{u}$ in Lithuanian, e.g. Lith. mūkà $2 / 4$ (OLith., dial.) 'torment', sūdžià 2 (OLith., dial.) 'judge', sũ das 2 (OLith., dial.) 'court of law, verdict', púdas 1 [1/2] 'pood

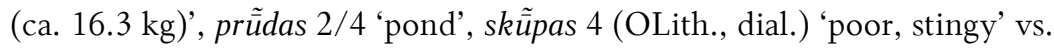
Latv. muõka, sùoǵis, sùods, puõds 'lispound', prùods' 'small natural pond', skùops, cf. Ru. múka, sud'já, sud, pud, prud, skupój. To my knowledge, there are only two Lithuanians examples with uo. One is kuodẽlis 'distaff'

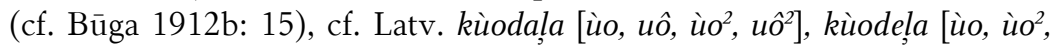
$\left.u \hat{o}^{2}\right]$ 'tow', Ru. kudél', which has a back-formation kuõdas 4 (Derksen 1996: 85-86). The other is kuokùlis (Žem.) 'corncockle, corn weed', which occurs alongside kūkãlis (also kūkõlis), cf. Latv. kuõkalis [uõ, ùo $\left.{ }^{2}\right]$ (also kuõkālis), Ru. kúkol'. On the other hand, there are Latvian forms with $\bar{u}$, e.g. kūkali (kūkāli 'corncockle', trũba 'tube, pipe', $\bar{u} d a\left[\tilde{u}, \grave{u}, \hat{u}, \hat{u}^{2}, \grave{u}^{2}\right]$ 'fishing-hook', ũsas 'moustache' $\left[\tilde{u}, \hat{u}^{2}, \grave{u}^{2}\right]$ alongside ùosas', cf. Lith. trūbà 4 (also triūbà

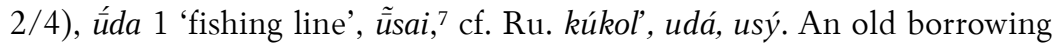
without Lithuanian counterpart is Latv. karuõgs 'banner, standard', cf. ORu. xorugy 'id.', OCS xorggy 'sceptre'.

Interestingly, several of the borrowings mentioned above show up in Finnic as well, e.g. Fi. kuontalo 'bunch', suntio 'verger', suunta 'direction', Est. sund 'order', und 'rod', Kar. muokka 'torment', Vot. muuka 'id.' (Bjørnflaten 2006: 58, 67). Unlike the corresponding East Baltic forms, where the reflex of the Proto-Slavic nasal vowel cannot be distinguished from the reflex of East Slavic $\bar{u}<* \bar{o}<* a u$ (see 2.4.), some of the Finnish forms have preserved the nasal element. According to Būga (1912a: 1-2;1925: 25-34), we find a small number of Slavic borrowings in Lithuanian that have retained the nasal element as well, viz. lénkas 'Pole', unguras (DP) 'Hungarian', and pundùs 3 (Žem.) alongside pùndas 1/3 'pood'. Bjørnflaten (2006: 67), without providing any argumentation, follows Kiparsky (1948: 37-39) in dismissing these forms as irrelevant to the issue, though Kiparsky's view has not become

7 Žem. uõstai 2/4 'moustache, whiskers (of an animal)' may very well not belong here (see Smoczyński 2018: 1565). 
the communis opinio. Kiparsky (l.c.) suggested that lénkas was borrowed from an unattested Polish source, but the view that it was borrowed from East Slavic at a stage when the root vowel of *lex $b$ had not yet lost its nasalization seems more popular (cf. LEW: 356; Zinkevičius 1987: 71; Smoczyński 2018: 687). Robinson (1973: 128) mentions lénkas as an example of acute tone in a borrowing of extreme antiquity. The ethnonym unguras $^{8}$ occurs three times in Daukša's Postilla (Gpl. Vngrų, Vngúru, Lpl. Vngurůse). Būga (1925: 34) rules out a German origin because the Lithuanians, he claims, never borrowed ethnonyms from German. Kiparsky (1948: 37) thinks that we should take Latin influence into account, which is considered doubtful by Zinkevičius (1987: 72) and Smoczyński (2018: 1561). The problem with an East Slavic origin is the fact that the evidence points to * $q g r$ - rather than * ggrr- (Smoczyński: l.c.). In the case of pundùs or pùndas the question is whether the word was borrowed directly from Germanic (Scandinavian or Low German) or through East Slavic (cf. Skardžius 1931: 193; LEW: 667). Būga's argument (1925: 28-29) for Slavic as an intermediary is that this unit of weight cannot be separated from birkavas, Latv. birrkavs 'shippound (20 lispounds)', which in view of the suffix must be based on Slavic *brrkovb, cf. Ru. bérkovec 'ten poods', a derivative of the name of the Swedish trading centre Birka. All in all, I think it is fair to say that Büga's traces of East Slavic nasal vowels cannot be dismissed out of hand.

\subsection{PSI. *o, *a}

In early borrowings from East Slavic, PSl. ${ }^{*} o$ is reflected as $a$ in both Lithuanian and Latvian, while PSl. * $a$ corresponds to Lithuanian $o$ and Latvian $\bar{a}$, e.g. Lith. grõmata (OLith., dial.) 'letter, document', kopũ stas 'cabbage', krosà (SD) 'paint, rouge', sopãgas (OLith., dial.) 'boot', Latv. grãmata 'book', kàpuõsts, krãsa [ã,à] 'colour, paint', zàbaks, cf. Ru. grámota 'official document', kapústa, krasá, sapóg. ${ }^{9}$ Recent borrowings show short reflexes ( $a$ and short $o$ corresponding to Russian $a$ and $o$, respectively) and may even reflect akan'e, e.g. Lith. gálstukas (V1.) 'necktie', karãblius (OLith., dial.) 'ship', pravoslãvas 'orthodox', Latv. burlaks 'robber' (Koškins 2019: 253), cf. Ru. gálstuk, korábl', pravoslávnyj, burlák. In Lithuanian villages with Lithuanian-Belarusian bilingualism, borrowings from the Soviet era may

8 The Standard Lithuanian word is veñgras, a borrowing from Polish. This form occurs in Daukša as well.

9 Due to the Lithuanian shortening of final acute syllables and the Latvian shortening of long vowels in final syllables, the Nsg. of the $\bar{a}$-stems deviates from the established pattern. 
show akan'e where Standard Lithuanian follows Russian orthography, e.g. in Lazūnai agranòmas, aparãcija for agronòmas, operãcija (Levin 2003: 145).

It is a well-known fact that before the rise of the new timbre distinctions there was a stage when $\mathrm{BSl} .{ }^{*} o$ had been delabialized to $* a$. This is reflected by borrowings from Slavic in a number of languages, including Greek and Finnic. The substitution of East Baltic * $a$ for the vowel that was to become Slavic $*_{o}$ is therefore natural. It cannot be denied, however, that we find the same correspondence after the rise of Slavic $*_{o}$ (see 4.3.). With respect to the substitution of Slavic * $a$, it should be noted that in certain East Lithuanian dialects (cf. Būga 1912a: 7-8; Zinkevičius 1966: 69) East Baltic ${ }^{*} \bar{a}$ is represented by $a \cdot$ or $\stackrel{a}{a}$, i.e. by a more open back vowel than $o$. In old texts from the western areas we occasionally find $a$ for $o$, e.g. szadei $=\check{z} o \tilde{d} z \check{i} i a$ 'words' in Mažvydas' Catechism (Stang 1966: 37-38).

\subsection{PSl. $* i<* e i$, PSl. $* u<* a u^{10}$}

In early borrowings of East Slavic origin, ${ }^{11} \mathrm{PSl} .{ }^{*} i$ corresponds to Lithuanian $y$, Latvian $\bar{l}$, e.g. Lith. dỹvas $2 / 4$ (OLith., dial.) 'miracle', čỹstas 4 (OLith., dial.) 'pure, chaste', ž̃̃das 2/4 'Jew', pyrãgas 'pie', bažnýčia 'church', Latv. dīva (or dīvs), ž̃̃ds, pìrãgs, baznîca, cf. Ru. dívo, čístyj, žid, piróg, božníca 'icon-case, (dial.) chapel'. Insofar as PSl. * $i$ continues *ei (rather than $* i H)$, we must reckon with the possibility that there are borrowings reflecting $*^{*}$, as this is the obvious intermediate stage. A parallel instance from Finnic is Kar. viehkurí 'whirlwind', which goes back to ORu. vixъrb (Mikkola 1894: 57; Būga 1912b: 16; Kallio 2006: 155), cf. Lith. víesulas. The most convincing East Baltic example is Latv. krievs 'Russian', which ethnonym originates from the Kriviči, an East Slavic tribe from the PskovPolotsk region (cf. Endzelin 1899: 285-286). Another form mentioned in this connection is OLith. mieras 'peace', Latv. miêrs 'peace', cf. Ru. mir. In my view (Derksen 2015: 316), the East Baltic forms are best regarded as inherited (pace Būga 1912b: 16). As observed in ALEW (647-648), the Latvian broken tone, which is uncommon in borrowings, may serve as an argument for a genetic relationship. The additional remark that the broken tone is in conflict with a reconstruction ${ }^{*}$ mei $_{1^{-}}$, as the stress was not retracted according to Hirt's law, is apparently based on an erroneous conception of this law.

\footnotetext{
${ }^{10}$ I have written *au because BSl. * $a u$ and *ou had merged in early Proto-Slavic.

${ }^{11}$ For some of the Lithuanian forms a Polish origin cannot be excluded.
} 
A more attractive instance of $i e$ corresponding to PS1. ${ }^{*} i<* e i$ is possibly the Latvian suffix -(e/i)niēks (cf. McKenzie 1919: 173). I have previously argued (1996: 185-186) that Lith. -(e/i)nỹkas was borrowed from Slavic, while Latv. -(e/i)niêks is probably inherited. This is still an option, but if we assume that Latvian borrowed the suffix at an earlier stage (or from a more archaic dialect), this would enable us to posit the same origin for both suffixes. The Karelian suffix -niekka 'potens v. gnarus rei' (Mikkola 1894: 57) may also reflect a PSl. stage $* \bar{e}$. Mikkola assumes that Finnic forms with ie $<* \bar{e}$ (besides -niekka and viehkuŕi, he mentions Kar. Viena 'Dvina' and miero 'paroecia, tractus ruralis, pagus') were borrowed from North Russian dialects where $i>e$, which I find unconvincing. With respect to Russian dialect forms that seem to show this phenomenon, Skach (2010: 139) proposes that we may be dealing with relics from dialects where the stage $*_{\bar{e}}<e i$ was preserved.

As for borrowings reflecting PSl. * $u$ from a $u$-diphthong (or of foreign origin), the East Baltic situation strongly resembles the one described in connection with East Slavic * $u<{ }^{*}$, e.g. Lith. bliūdas 2 (OLith., dial.) 'dish', kũ̄mas 2 'godfather', kūmà 2/4 'godparent', dūmà 2 (OLith., dial.) 'thought,

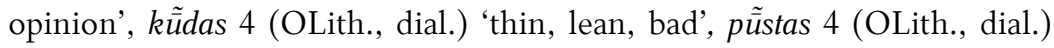

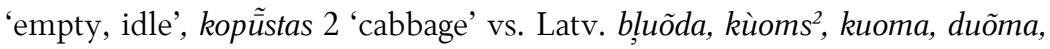
kuods, puõsts, kàpuõsts, cf. Ru. bljúdo, xudój, kum, kumá, dúma, skupój, pustój, kapústa. Some of the Latvian forms have doublets with ü: kũms 'godfather', kũma 'godparent', kũds, pũsts 'ein wüster, sumpfiger Wald'. Other Latvian forms are only found with $\bar{u}$, e.g. Latv. dũda 'bagpipe', pũka '(particle of) down, fluff' (but puõkaiņš 'rauhhaarig, befiedert'), Lith. dūdà 2/4, pũ kas 4, cf. Ru. dúdka, pux, trubá. Remarkably, we have uo in Žem. puõkas 4 '(particle of) down' (Būga 1959: 671).

\subsection{PSl. *̌̀}

It appears that there is a clear difference in the way PSl. *ě is reflected in early Lithuanian and Latvian borrowings from East Slavic. In general we find we find $i e$ in Lithuanian, but $\bar{e}$ in Latvian, e.g. Lith. griêkas 2/4 (OLith., dial.) 'sin', mierà 4 [1/4] (OLith., dial.) 'measure', sierà 4 'sulphur', viestis (OLith.) 'news' vs. Latv. grẹ̀ks, mệrs, sêrrs, vèsts, cf. Ru. grex, méra, séra, vest'. A Latvian example with $i e$ is miẽsts 'small village'. After palatal consonants (ččs, ž), however, Lith. has $\dot{e}$ for $a<* \check{e}$, e.g. čésas 2/4 (OLith., dial.) 'time', žễlava / žếlaba (dial.) 'mourning', cf. Latv. žêlabas, žệl 'sorry, pity', Ru. čas, žáloba, žal'. It could be argued that Lith. nedélia 'Sunday, weekend', cf. 
Latv. nedêla, was borrowed at a different stage, but it seems more plausible that the $\dot{e}$ is analogical after déti 'do' (Būga 1912a: 9). In the case of bédà 'misfortune, trouble, guilt', Latv. bẹda 'care, sorrow, grief' we may be dealing with inherited forms, but the matter is complicated (cf. Derksen 2015: 85).

In the Aukštaitian dialects of Lithuanian, *ie as a substitution for PSl. * ě cannot be distinguished from ie $<* \bar{e}<* e i / * a i$. The Žemaitian situation is different, as was already noted by Būga (1912a: 7-8). The borrowings have $i e$, e.g. griếks, while the reflexes of East Baltic ${ }^{*} \bar{e}$ vary from ẹi to $i$. (see also Zinkevičius 1966: 86).

\subsection{PSI. *b, *b}

It is clear that the earliest East Baltic borrowings from East Slavic predate the stage when the jers in weak position were lost and the jers in strong position merged with ${ }^{*} o$ and ${ }^{*} e$. PSl ${ }^{*} b$ is reflected as $u$, e.g. Lith. kùrtas 1 'greyhound', pulkas 4 'regiment', tùlkas 1 [1/2] (Bretkūnas, dial.) 'interpreter', tur̃gus 2 [2/4] 'market', Latv. kur̃ts, pùlks [ùl, ũ̃], tuilks, cf. Ru.

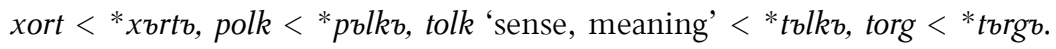
$\mathrm{PSl}{ }^{*} b$ is reflected as $i$, e.g. bìrkavas 'shippound' (see 2.2.), krikštyti 'baptize', Póvilas 'Paul', stìklas 4 'glass', Latv. birrkavs, kristît, Pãvils, stikls, cillvệks 'man, person', cf. Ru. bérkovec (derived from *bbrkovb), krestit' < *krbstiti, Pável $<*$ Pavblb, čelovék < * čblověkb. The form cillvệks points to borrowing from a dialect showing cokan'e (Young 2009: 183; Koškins 2019: 251-252).

According to Būga (1925: 39-40), Žem. cìrkva 'church' is an earlier borrowing than E. Lith. cer̂rkve, which reflects East Slavic *cerkv- < ${ }^{*} c r k b v-$. The Žemaitian form is assumed to represent a stage when the jers in weak position had been lost, but $*_{b}>e$ had not yet occurred. Other words that may have been borrowed at more than one stage are Lith. bulvõnas 'pagan idol', Latv. buĩvāns 'ausgestopfter Vogel, um Wild herbeizuziehen; ein Lockvogel' alongside Lith. balvõnas, Latv. balvāns (Būga 1925: 40, 43, 47), cf. Ru. bolván < *bblvanb, and Latv. buca vs. Lith. bačkà 2/4 'barrel', cf. Ru. bóčka. The Latvian noun must be based on *brca, with cokan'e.

\subsection{PS1. *y}

To my knowledge, there are no borrowings with $* \bar{u}$ corresponding to PSl. * $y$. We must keep in mind, however, that it might be difficult to distinguish these very early borrowings from inherited forms. In Finnic, Votic sūra- 'cheese', cf. Ru. syr, may be the only example (Kallio 2006: 
155). In East Baltic, the regular substitution for the unfamiliar vowel * $y$ is ui, e.g. Lith. muĩtas 2 'customs, duty', Latv. muĩta, cf. Ru. mýto. Of special interest are borrowings with $u i$ after $k$ or $g$, reflecting PSl. * $k y$, * $g y$, or *xy, as in East Slavic these sequences developed into ki, gi, $x i$. The latter stage is reflected by kỹtras 'sly, clever', Latv. nekîtrs 'obscene, filthy', cf. Ru. xítryj. In the case of Lith. kùila 'rupture, hernia', cf. Ru. kilá 'rupture, hernia' < *kyla, there is a variant with ${ }^{*} \bar{\imath}$, viz. Lith. kýla $1[1 / 4]$. The same holds true for the etymologically related Latv. kuĩlis 'boar', cf. Lith. kuilỹs 4 [2/4] 'boar', which has a variant kil ${ }^{2}$. Smoczyński (2018: 542-543) suggests that kýla 1 is a borrowing from Polish, while kylà 4 was borrowed from Belarusian. Būga (1925: 52), on the other hand, assumes that kýla must be a relatively old borrowing from Belarusian because of its acute. The fact that both Dybo (1981: 22) and Zaliznjak (1985: 132) classify kyla as belonging to AP (a) is relevant in this respect. Accentuation will be the subject of the next section.

\section{Accentuation}

In his study of tone in Latvian borrowings from Old Russian, Young (2009: 189) has shown that long syllables which were stressed throughout the paradigm in Old Russian have sustained tone in Latvian. A falling tone is found when, in Young's formulation (2009: 190), a long syllable was either pretonic or occurred in an enclinomenon form of the mobile paradigm. Which syllables were pretonic in the East Slavic forms is a matter that is open to discussion. The fact remains that, generally speaking, the sustained tone is linked to AP (a) and the falling tone to (b) and (c). In Kortlandt's interpretation (2009: 81), the evidence discussed by Young indicates that in Old Russian glottalization had been preserved at the time of borrowing. In Latvian, where glottalization has been preserved outside the stress as the so-called broken tone, stressed glottalized syllables ultimately received a sustained tone.

This is not a suitable occasion for a comprehensive study of the accentuation of Lithuanian borrowings from Slavic. It is clear that to a large extent circumflex tone is a characteristic of Slavic borrowings, but this is not necessarily true of borrowings of great antiquity (cf. Robinson 1973: 128). Examples of borrowings with an acute root are kálpas 1, kùrtas 1, tùlkas 1

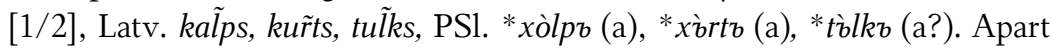
from the correspondence $k: x$ in the first two etyma, these nouns behave as if they were Balto-Slavic. Other borrowings with an ostensibly "BaltoSlavic” acute are Lith. bìrkavas, kùila / kýla, Póvilas, šálmas, Latv. birrkavs, kal̃ps, kuĩlis, Pãvils. We may tentatively add Žem. cìrkva, cf. Ru. cérkov' from 
*cbrky (a) (Zaliznjak 1985: 133). ${ }^{12}$ An acute suffix is found in Lith. bažnýčia, Latv. baznîca. The broken tone of the Latvian suffix may be secondary (cf. Young 2009: 183). The acute of Lith. biesas $1 / 3$ is unexpected in view of the mobility of PSl. *běs (c), but the tone may have been influenced by inherited forms from the same root ${ }^{*} b^{h}(o) i H\left(d^{h}\right)$-, cf. Latv. bitties 'be afraid'. No such explanation is possible for svietas 1 (alongside sviẽtas 2) 'world, people', cf. PSl. *suětr (c).

Smoczyński (2018: 641) calls the acute of kùrtas historically unmotivated, referring to kùrva 'whore', tùlkas, kùila, and válnas 'free' as other instances of an unmotivated acute in a borrowing. This suggests that in Lithuanian borrowings from Slavic acute tone is regarded as unmotivated by definition. Though it will hardly be possible to account for all instances, I think we should at least try to make a few relevant observations, for instance that the stage at which a word was borrowed seems to play a role. David Robinson (1973: 128) claims that "the diphthongs áu, ár, and ál found in loanwords will always have acute intonation when stressed". This is an attempt to explain the acute on phonetic grounds. Since the first part of acute diphthongs is relatively long and the Lithuanian long $a$ has a quality closer to the Slavic $a$ than does the short $a$, the motivation for the acute tone is phonetic resemblance. Unfortunately, Robinson does not present a single example, apart from Lith. -áuskas vs. Pl. -owski (l.c.), if I understand him correctly, but here we have Slavic $o$. In view of the developments discussed in 2.1. and 2.2. we would not expect Robinson's observation to apply to old borrowings anyway. It may, however, have some relevance with respect to relatively recent borrowings such as Lith. kárdas 'a type of short sword', kárpis 'carp', páltis 'overcoat', stérva (OLith., dial.) 'carrion, carcass', cf. ORu. kordb, Pl. kord, Ru. karp, Pl. karp, Ru. pal' tó, stérva < *stbrva, but this falls outside the scope of this paper.

We have seen a number of borrowings that show agreement between Lithuanian and Latvian and I suspect that at least some of them belong to an early layer. It is not possible, however, to establish a distribution that is parallel to the one that Young has established for Latvian, cf. Lith. grõmata, muĩtas 2, mūkà 2/4, vs. Latv. grãmata, muĩta, muõka. Other Lithuanian forms with a circumflex corresponding to AP (a) in Slavic are čystas 4, diẽdas 4, sylà $2 / 4$, Ru. čistyj, ded, síla.

12 Pronk-Tiethoff (2013: 102) states that Zaliznjak's AP (a) cannot be correct (for Proto-Slavic), but Zaliznjak bases himself on Old Russian data, which in this case is all we need. 


\section{Chronology}

\subsection{Historical Background}

According to Young (2009: 178), the Latvian borrowings from Old Russian date from approximately the 7th and 8th centuries to the 13th century, when German political and cultural dominance was on the rise (cf. Koškins 2020: 250, 255). This is also the timeframe that I have in mind with respect to the subject of this study. For the Lithuanian data this means that in principle we are not concerned with borrowings from the times of the Grand Duchy of Lithuania, whether they are Polish or East Slavic. Of course, it is often difficult to ascertain in which period a word was borrowed. Good candidates for early borrowing are, for instance, words connected with trade or religion that we also find in Finnic.

A quick survey of the material suggests that the oldest layer of Slavic borrowings in Latvian predates the oldest layer of Slavic borrowings in Lithuanian. McKenzie (1919: 171) finds it unattractive that Lithuanian and Latvian should have borrowed the same Slavic words with $* \bar{o}(>* \bar{u})$ at different times, as had been argued by Būga (1912b). He therefore suggests that in Lithuanian the development $* \bar{o}>u o$ had already taken place or that Russian ${ }^{*} \bar{o}$ somehow differed from Lithuanian ${ }^{*} \bar{o}$. This is in itself a possible scenario, but to me this early diphthongization seems unconvincing and not in line with the essence of his argumentation. The merit of McKenzie's article lies in his demonstration that Lithuanian and Latvian ie and uo did not originate in Proto-Baltic or Proto-East Baltic but developed from ${ }^{*} \bar{e}$ and ${ }^{*} \bar{o}$. McKenzie (1919: 170, 172-173) rightly criticizes Būga for assuming that the forms were borrowed from an Old Russian dialect where diphthongization had taken place, as this is in conflict with the Finnic evidence. Generally speaking, however, it is difficult to rule out the possibility that Lithuanian and Latvian were in contact with varieties of East Slavic that differed considerably from one another. The Latvians are assumed to have had trade relations with the Kriviči of the Pskov-Polotsk region (cf. Young 2009: 178-179). A characteristic of the language of the Kriviči is cokan'e, which is supposed to be reflected by such Latvian borrowings as cilvệks (see 2.6.), provided that we could have $\check{c}$ in such an early borrowing.

In the following discussion of the chronology of various Baltic and Slavic developments I shall use the elaborate relative chronology devised by Kortlandt as a point of reference, occasionally referring to publications by Holzer, whose relative chronology attempts to integrate Baltic and Slavic developments. 


\subsection{Terminus a quo}

Though it is clear that at the time of their expansion the speakers of Slavic still had diphthongs (cf. Holzer 2001: 39-41; Kallio 2006: 159-161; Vermeer 2015: 1), our East Baltic material contains no traces of retained *au and $* a i / * e i$, while in Finnic there may be a few early borrowings from Slavic reflecting a diphthong (Kallio: l.c.). Obviously, this could mean that we have simply failed to identify the relevant forms owing to their deceptively BaltoSlavic appearance. The matter will not be pursued here. To all appearances the East Baltic languages seem to have borrowed from a Slavic dialect that had undergone the palatalizations and the monophthongization of diphthongs. In Kortlandt's relative chronology (e.g. 2003: 216-217, 232) these developments belong to his Early Middle Slavic period. Holzer, whose Urslavisch is dated around $600 \mathrm{AD}$, regards the aforementioned developments as nachurslavisch (1998: 39fn.; 2001: 39-40). This is compatible with onomastic evidence showing that the second palatalization had not yet occurred shortly before the middle of the 6th century (Vermeer 2015: 5).

\subsection{Proto-Slavic quantity}

At a superficial glance the East Baltic borrowings faithfully preserve Proto-Slavic quantity. This cannot be the case, however. In Proto-Slavic, PIE lengthened grade vowels and sequences of a vowel plus a laryngeal (instances of Winter's law included) had the same timbre, but due to a number of developments, such as pretonic shortening or the loss of the laryngeal feature in stressed syllables, the vowels that are traditionally labelled as long could actually be either long or short. Furthermore, the old short vowels had under certain conditions been lengthened. The problem was recognized by Stang (1957: 52-55), who assumes that the substitution rules were originally based on length distinctions and subsequently became traditional. They still apply to relatively late borrowings from Polish, for instance. I rather agree with Levin (1972: 152; 2003: 141-142) that the substitution is phonologically motivated. Here we must obviously take into account that at the time of borrowing the East Baltic vowel systems differed from the systems of Modern Standard Lithuanian and Latvian. Levin (2003: 140) suggests, for instance, that Standard Lithuanian /o:/ vs. /a/ continues Common Lithuanian /a:/ vs. $/ \mathrm{p} /$.

\subsection{The rise of the new timbre distinctions and polnoglasie}

Since the Slavic word for 'king', i.e. *kòrly, which derives from Charlemagne, was apparently borrowed before the elimination of the liquid 
diphthongs, the latter development cannot be dated before the second half of the 8th century. According to Kortlandt (2003: 219-220, 232), the metathesis of liquids preceded the rise of the new timbre distinctions in South Slavic and Czecho-Slovak, whereas in Lechitic and Sorbian we find the reverse chronology. In his framework both developments are Late Middle Slavic. The East Slavic pleophony is dated to the Late Proto-Slavic period, which is significantly later. Bjørnflaten, who regards the elimination of the liquid diphthongs as an abrupt sound change (2006: 55), may be inclined to overestimate the antiquity of polnoglasie. His timeframe for the elimination is $750-850$.

It is noteworthy that Latvian borrowings with ie or uo corresponding to Slavic $* \bar{i}<* \bar{e}<* e i$ or $* \bar{u}<* \bar{o}<* a u$ must have been borrowed before the raising of $* \bar{e}$ and $* \bar{o}$ and therefore before the rise of the new timbre distinctions and polnoglasie. It is therefore not surprising that we find several borrowings that reflect a liquid diphthong. The corresponding Lithuanian forms date from after the rise of the new timbre distinctions, but there are some forms that seem to predate the East Slavic pleophony. Both Kortlandt (2003: 219) and Holzer (2001: 40-41) point out that the Slavic development $* b j>* b l$ was anterior to the raising of ${ }^{*} \bar{e}$ and ${ }^{*} \bar{o}$, cf. Latv. bluõ $d a$, which in Holzer's case is explicitly mentioned as an argument for what he calls the "Slavisch-lettische l-Epenthese". Another Slavic development that must have preceded the raising is the delabialization of * $\bar{u}$ to $\bar{y}$ (Kortlandt: 2003: 219; Holzer 2001: 41). As to the Baltic side of the chronology, I would like to note that is very likely that the East Baltic monophthongization of stressed *ei and *ai to ${ }^{*} \bar{e}$ had already taken place at the time of the earliest Latvian borrowings.

\subsection{Denasalization and the raising of jat'}

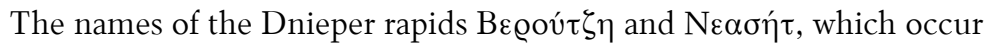
in Constantine VII Porphyrogenitus' De administrando imperio (ca. 950), have been adduced as early instances of denasalization since the 19th century (e.g. Mikkola 1894: 49). These forms are normally interpreted as reflexes of *vbroči 'seething' and *nejęsytr 'insatiable', respectively. The Russian name of the Varangian Igor' (from Ingvarr or Ingvorr), who according to the Primary Chronicle ruled Kievan Rus' from 912 to 945, also indicates that the nasal vowels had been lost because otherwise we would have expected the name to begin with $J a-$. The latter reflex is found in Ru. varjág 'Varjagian' < *varegr from Vxringr. This borrowing may be dated to the 9th century (see Kiparsky 1979: 77-78 for more examples pointing to retained nasals vowels). Whereas there seem to be no examples of early Finnic borrowings 
from Slavic reflecting *e (Mikkola: l.c.), there are, as we have seen, plenty of instances where the Slavic form contained* $q$. The oldest layer appears to reflect the nasal element as $n$. It seems plausible that the earliest borrowings also reflect the different quantity of the nasal vowels (cf. Mikkola 1894: 48, Kiparsky 1979: 82-84), which can hardly serve, however, as an argument for the West Slavic origin of these accessions (pace Bjørnflaten 2006: 58-59, 72). In my view, it is unlikely that East Slavic no longer had phonemic length at this early stage.

The East Baltic substitutions for * $q$ and * $q$ show no trace of nasalization, a few Lithuanian forms excepted (see 2.2.). In the case of $*$, we find a vowel that is identical with the reflex of Proto-East Baltic $* \bar{e}$, which in early Lithuanian and Latvian must have been realized as [æ:] or [ع:]. Under certain conditions the same vowel is substituted for $* \check{e}$ and for * $a$. In the case of * $q$, we find $u o$ and $\bar{u}$ in both Lithuanian and Latvian. In Latvian, $u o$ is much more common, however. This is reminiscent of the situation that we find regarding $* \bar{u}<* \bar{o}<* a u$, which suggests that in this particular variety of Slavic $* \bar{o}<* q$ and $* \bar{o}<* a u$ merged and were later raised to $* \bar{u}$. The Finnic evidence seems to support this scenario. I fail to see how the nasalization could have been lost in Lithuanian or even Latvian rather than already in East Slavic. In Latvian, *an /_C and *un /_C yielded *uo and *u, respectively, but that must have been a recent development, and besides, *an is an unexpected substitution for Sl. * $q$. Moreover, * en /_C would yield ie rather than the attested $\bar{e}$ (thus also Bjørnflaten 2006: 67).

In Kortlandt's chronology, the raising of ${ }^{*} Q$ to $* u$ is dated to the end of the Late Proto-Slavic period, followed immediately by denasalization of all nasal vowels in East Slavic. As we have seen, the bulk of the East Baltic evidence shows no trace of a nasal, except for a few Lithuanian forms, to which we shall now return. The sequence en in Lith. lénkas may reflect Slavic *e. The sequence un in pundùs / pùndas and unguras may reflect Slavic *u, which would be at odds with the development $* \varphi>*_{\bar{o}}$ posited above, or perhaps $*^{*}$, as the latter is closer to un than to an. In any case, un finds no support in Latvian, cf. Latv. puõds. We may be dealing here with variation in the East Slavic donor language. Note that both the Lithuanian and the Latvian forms point to an acute root.

Slavic *ě must originally have been a low monophthong. This is in agreement with the Latvian evidence, where we find $\bar{e}$. In Lithuanian, the regular substitution for * ${ }_{e}$ is $i e$ and not $\dot{e}$, however, which is an indication that in the donor language the raising of $* \check{e}$ had already taken place. Kortlandt (2003: 222) dates this raising, which also occurred in part of the West and 
South Slavic areas, to his Young Proto-Slavic period, after polnoglasie. Since Aukštaitian $i e$ originates from $* \bar{e}$, the latter vowel would be a highly plausible substitution for *ě , provided that * $e^{2}$ had been raised to *ẹ. On the other hand, the fact that in Žemaitian Slavic borrowings also have ie, which in these dialects is not the regular reflex of Proto-East Baltic *e, seems to indicate that in the donor language $* \check{e}$ had been diphthongized. I therefore agree with Kortlandt's formulation "raising of $\check{e}$ from $\ddot{a}$ to $i e$ " (2003: 222). The difference between Lithuanian and Latvian regarding their treatment of $* \check{e}$ is in agreement with other observations which seem to indicate that Latvian has an older layer of Slavic borrowings (cf. Bjørnflaten 2006: 67-68), but we must not forget that there may also be a geographical dimension. In Kriviči territory, * ${ }^{2}$ was realized, according to Zaliznjak (2004: 52), either as an open monophthong or as a diphthong with an open second component, which he links to North West Russian dialect forms such as jála for jéla or kjap for cep. In the Novgorod birchbark texts, confusion between $\check{e}$ and $i$ only begins in the second half of the 12th century (Zaliznjak 2004: 26, 52-53).

\subsection{The jers and *y}

Kallio (2006: 155) questions Kiparsky's decision to reconstruct a ProtoRussian vowel system with $\dot{i}$ : $\left({ }^{*} y\right)$ vs. $u, i\left(>^{*} b,{ }^{*} b\right)$ as the donor language for Finnic borrowings (cf. Kiparsky 1979: 80). Following Kortlandt (e.g. 2003: 219 ), he would prefer the delabialization of of $* u$ and $* \bar{u}$ to coincide. We must ask ourselves if the delabialization of *u or more in general the rise of the jers (within the context of the rise of the new timbre distinctions) would be reflected in either Finnic or East Baltic. Prior to the elimination of the jers, which in the East Slavic area is assumed to have started in the 12th century, ${ }^{13} u$ and $i$ are substituted for ${ }^{*} b$ and ${ }^{*} b$, respectively. These uniform substitutions shed no light on the rise of the jers.

The East Baltic substitutions for East Slavic * $y$ offer hardly any information about the time of borrowing. An exception are the sequences $* k y$, *gy, and * xy. According to Būga (1925: 50), the change $y>i$ after velars is first found in the mid-12th century in Ukrainian Church Slavic - Kiparsky (1979: 140) has a few earlier examples - and was not yet completed at the beginning of the 14th century in the area around Novgorod. In what Būga calls the Belarusian area around Smolensk, Vitebsk, and Polotsk, the change must have occurred somewhere in between. This provides a terminus ante quem for such forms as Lith. kùila 'hernia', kuilỹs, Latv. kuĩlis 'boar'.

13 This chiefly applies to the merger of ${ }^{*} b$ and ${ }^{*} b$ with $e$ and $o$. The loss of the jers in weak position was earlier and depended on their position. 


\subsection{Accentuation}

Kortlandt's claim that the earliest East Slavic borrowings in Latvian show that at the time of borrowing Russian had preserved glottalization under the stress is in keeping with his relative chronology, since the borrowings display several features that point to a stage anterior to "the [Late ProtoSlavic] loss of the acute (broken, glottalic) tone" (2003: 233), for instance the raising of $*^{*} \bar{e}$ and ${ }^{*} \bar{o}$. An exception is the raising and denasalization of $*$ (see 4.5.). If we follow Kortlandt's relative chronology, at least some words must have been borrowed before Dybo's law, when Slavic had a contrast between glottalized, rising and falling initial syllables. If at that stage Latvian, apart from broken tone, had possessed a contrast between falling and rising tones, one would have expected to see this reflected in the treatment of forms which in Slavic belonged to AP (b) or (c). The same argument, in fact, could be applied to the period between Dybo's law and the loss of the glottalic feature. In my view, it is plausible that the accession of the early borrowings preceded the rise of the Latvian tones. The retractions of the ictus from which the tonal contrasts originate must be dated to the end of the East Baltic period and were posterior to the monophthongization of * $e i$ and *ai under the stress. In Lithuanian, the state of affairs is entirely different. Borrowings characteristically have circumflex tone, even if the Slavic form had an acute. There are exceptions, however. These can partly be explained by assuming that the relevant forms were borrowed at the same early stage as the Latvian forms that have a sustained tone corresponding to a Slavic acute.

An interesting case is Lith. grõmata, Latv. grãmata, in view of the fact that Kortlandt presents Ru. grámota as an example of his Russian lengthening of short rising vowels (2003: 225). The lengthening occurred after the loss of the acute, which yielded a short rising tone. Since grámota continues Gk. $\gamma \varrho \alpha \mu \mu \alpha \tau \alpha$, it is unlikely that the short rising tone resulted from the loss of glottalization. The word may have entered Slavic at any time after the operation of Dybo's law, since the law would have shifted the stress. It is not possible to link all Latvian borrowings with a sustained tone to the lengthening of short rising vowels because this would not match the distribution established by Young, not to mention other issues pertaining to relative chronology.

\section{Conclusions}

A survey of the early Slavic borrowings in East Baltic leads to the conclusion that in general the Latvian borrowings seem to belong to an older 
layer than the forms that we find in Lithuanian. This is borne out by both the phonological and the accentual evidence. The early Finnic borrowings from Slavic present a picture that seems closer to the Latvian than to the Lithuanian situation, which invites the question of to what extent our topic is connected with East Slavic dialect geography. The Russian dialects of the area nearest to the Finnic and Latvian territories may have been more archaic than the dialects that were spoken in the area nearer to Lithuania. This is mainly speculation, however, as we have insufficient data. Material gathered in the 19th and 20th centuries has only limited value (cf. Wiemer and Seržant 2014: 39, 42).

If we once again employ Kortlandt's Slavic relative chronology as a point of reference, for clarity's sake adding his numbering of the developments between brackets, there seem to be no East Baltic borrowings that necessarily reflect a stage prior to the assimilation of $j$ to a preceding consonant (7.6), which includes $* b j>* b$, and the delabialization of high vowels (7.8). In Latvian, however, there are plenty of forms that must have been borrowed before the raising of ${ }^{*} \bar{e}<* e i$ and $* \bar{o}<* a u$ (7.9). Furthermore, most Latvian

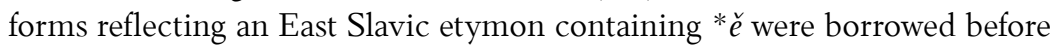
the raising to $i e(8.3)$ and we find a few examples of forms that do not reflect polnoglasie (9.1). Finally, the accentuation of the Latvian forms indicates that the East Slavic loss of glottalization (9.2) had not yet occurred. The only real issues are the raising of $*_{\varphi}(9.6)$ and the denasalization of the nasal vowels (9.7). The Latvian data seem to point to denasalization of ${ }^{*} q$ at an earlier stage. It is likely that in the East Slavic area bordering the Latvian linguistic territory the denasalization preceded the raising of * $\check{e}^{2}$ and perhaps the raising of ${ }^{*} \bar{o}$, in which case $* \bar{o}<{ }^{*}$ q merged with ${ }^{*} \bar{o}<* a u$.

East Slavic borrowings in Lithuanian seem to have entered the language after the raising of $*_{\bar{o}}<* a u$ (7.9) and after the raising of $* \check{e}$ to ie (8.3). There are a few forms that were probably borrowed before polnoglasie (9.1). The accentuation of the borrowings makes it likely that the majority were introduced into the language after the loss of glottalization in East Slavic (9.2). There are some interesting exceptions, however. The raising of $q$ (9.6) and the subsequent denasalization of the nasal vowels (9.7) are not in conflict with the data, apart from the fact that there are two forms which show the same development to $u o$ as in Latvian, suggesting that denasalization preceded raising. In addition, there a few etyma that may have been borrowed before denasalization.

As to the East Baltic side of the matter, it seems plausible to me that the accession of the East Slavic borrowings was posterior to the East Baltic 
monophthongization of stressed $* e i$ and $* a i$ to $* \bar{e}$, but that in Latvian most borrowings were adopted before the rise of tonal distinctions (other than the broken tone), which resulted from the retractions of the ictus from prevocalic $i$ and final *- $a$ (cf. Derksen 1996: 374-376; 2015: 19-20). In Lithuanian, the accession of the majority of the borrowings was posterior to these retractions, which marked the disintegration of East Baltic.

\section{Abbreviations}

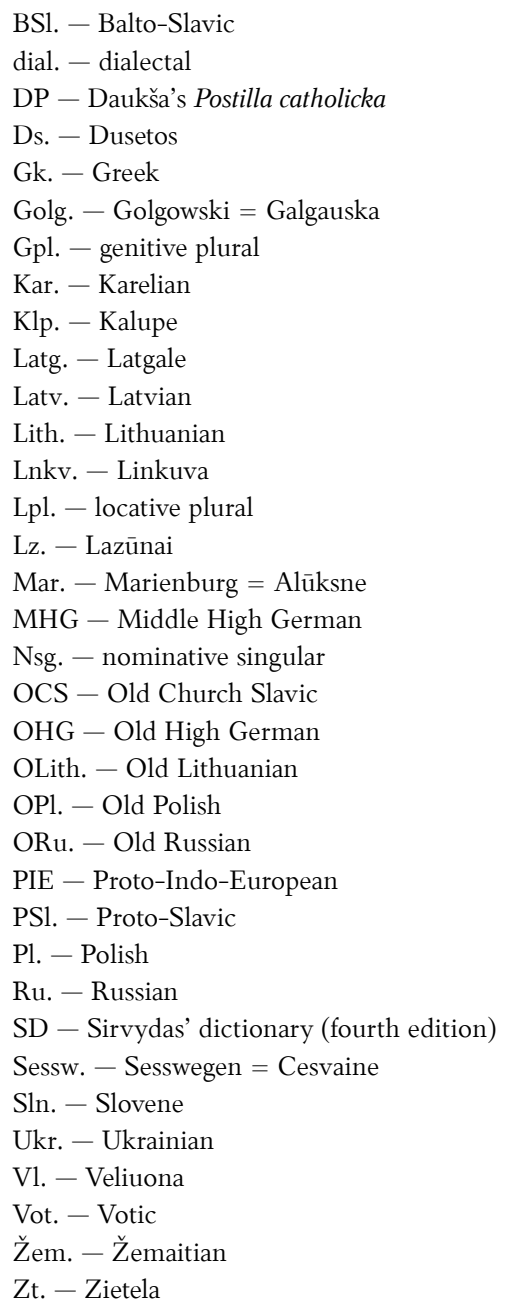




\section{References}

ALEW $=$

Bjørnflaten, Jan Ivar. 2006.

Brückner, Alexander. 1877. Būga, Kazimieras. 1912a.

Būga, Kazimieras. 1912b.

Būga, Kazimieras. 1922.

Būga, Kazimieras. 1925.

Būga, Kazimieras. 19581962.

Būga, Kazimieras. 1959. ${ }^{14}$

Derksen, Rick. 1996.

Derksen, Rick. 2015.

Dybo, Vladimir A. 1981.

Eckert, Rainer. 1973.

$\mathrm{EH}=$

Endzelin, Jan. 1899.

Endzelin, Jan. 1922.

Endzelīns, Jānis. 19711982.

Holzer, Georg. 2001.
Altlitauisches etymologisches Wörterbuch. Unter der Leitung von Wolfgang Hock und der Mitarbeit von Elvira-Julia Bukevičiūtè und Christiane Schiller bearbeitet von Rainer Fecht, Anna Helene Feulner, Eugen Hill und Dagmar S. Wodtko. Hamburg: baar, 2015.

Chronologies of the slavicization of Northern Russia mirrored by Slavic loanwords in Finnic and Baltic. Juhani Nuorluoto (ed.), The slavicization of the Russian North. Mechanisms and chronology (Slavica Helsingiensia 27). Helsinki, 50-77.

Die slavischen fremdwörter im litauischen. Weimar: Böhlau.

Lituanica. 1. K voprosu o xronologii litovskix zaimstvovanij s russkogo. Izvěstija otdělenija russkago jazyka i slovesnosti Imperatorskoj Akademii Nauk 17(1), 1-14 (= Rinktiniai raštai I, 339-350).

Lituanica. 2. Litovsko-latyšskie uo i ie v zaimstvovannyx s russkogo slovax na meste ožidaemyx $\bar{u}$ i $\bar{l}$. Izvěstija otdèlenija russkago jazyka i slovesnosti Imperatorskoj Akademii Nauk 17(1), 14-16 (= Rinktiniai raštai I, 351-353).

Kalba ir senove I. Kaunas: Švietimo Ministerijos leidinys (= Rinktiniai raštai II, 7-329).

Die litauisch-weißrussischen Beziehungen und ihr Alter. Zeitschrift für slavische Philologie 1, 26-55 (= Rinktiniai raštai III, 749-778).

Rinktiniai raštai I-III. Sudarė Z. Zinkevičius. Vilnius: Valstybinė politinès ir mokslinès literatūros leidykla, 1958-1962.

Zamečanija i dopolnenija k ètimologičeskomu slovarju russkogo jazyka. Rinktiniai raštai II, 499-694.

Metatony in Baltic. Amsterdam-Atlanta: Rodopi.

Etymology of the Baltic inherited lexicon. Leiden-Boston: Brill. Slavjanskaja akcentologija. Moskva: Nauka.

Zur Frage der frühen Lehnbeziehungen zwischen Slawisch und Baltisch. Baltistica 9(1), 49-65.

Endzelin, J., and Hausenberg, E. Ergänzungen und Berichtigungen zu K. Mühlenbachs Lettisch-deutschem Wörterbuch (= Endzelīns, J. and Hauzenberga, E., Papildīnajumi un labojumi K. Mühlenbacha Latviešu valodas vārdnīcai). I-II. Riga: Lettisches Kulturfonds / Grāmatu apgāds, 1934-1946.

Latyšskie zaimstvovanija iz slavjanskix jazykov. Živaja starina 3, 285-312 (= Darbu izlase I, 80-112).

Lettische Grammatik. Riga: Gulbis.

Darbu izlase I-IV. Rīga: Zinātne.

Zur Lautgeschichte des baltisch-slavischen Areals. Wiener slavistisches Jahrbuch 47, 33-50.

${ }_{14}$ The (unfinished) manuscript dates from ca. 1918. 
Kallio, Petri. 2006.

Kiparsky, Valentin. 1948.

Kiparsky, Valentin. 1979.

Kortlandt, Frederik. 2003.

Kortlandt, Frederik. 2009.

Koškins, Igors. 2000.

Koškins, Igors. 2019.

Kroonen, Guus. 2013.

Levin, Jules F. 1972.

Levin, Jules F. 2003.

$\mathrm{LEW}=$

$\mathrm{LKŽ} \mathrm{=}$

$\mathrm{ME}=$

McKenzie, Roderick. 1919.

Mikkola, Jooseppi. J. 1894.

Pronk-Tiethoff, Saskia.

2013.

Robinson, David F. 1973.

Shevelov, George Y. 1964.
On the earliest Slavic loanwords in Finnic. Juhani Nuorluoto (ed.), The slavicization of the Russian North. Mechanisms and chronology (Slavica Helsingiensia 27). Helsinki, 154-165

Chronologie des relations slavobaltiques et slavofinnoises. Revue des Études Slaves 24, 29-47.

Russian historical grammar. I: The development of the sound system. Translated from the German by J. Ian Press. Ann Arbor: Ardis.

Early dialectal diversity in South Slavic II. Jos Schaeken, Peter Houtzagers, and Janneke Kalsbeek (eds.), Dutch Contributions to the Thirteenth International Congress of Slavists. Amsterdam-New York: Rodopi, 215-235.

Accent retraction and tonogenesis. Thomas Olander and Jenny Helena Larsson (eds.), Stressing the past. Papers on Baltic and Slavic accentology. Amsterdam-New York: Rodopi, 75-82.

Senkrievu aizguvumu latviešu valodā vēsturiski valodniecisks vērtējums. Baltu filolog̣ija 9, 39-50.

Latviešu valodas kontakti ar slāvu valodām. Ilga Jansone et al. (eds.), Latvija: kultūru migrācija. Rīga: LU Akadēmiskais apgāds, 250-280.

Etymological dictionary of Proto-Germanic. Leiden-Boston: Brill.

Slavic borrowings in the Elbing Vocabulary and their implication for Prussian phonology. General Linguistics 12(3), 149-158.

The North Slavic-Lithuanian contact area: mutual influence and resistance. Robert A. Maguire and Alan Timberlake (eds.), American Contributions to the 13th International Congress of Slavists, Lubljana 2003. Volume I: Linguistics. Bloomington, IN: Slavica, 139-148.

Fraenkel. Ernst. Litauisches etymologisches Wörterbuch. I-II. Heidelberg-Göttingen: Winter, Vandenhoeck \& Ruprecht, 1955-1965.

Lietuvių kalbos žodynas. I-XX. Vilnius: Mokslas / Mokslo ir enciklopediju leidybos institutas, 1941-2002.

K. Mühlenbachs Lettisch-deutsches Wörterbuch. Redigiert, ergänzt und fortgesetzt von J. Endzelin (= K. Mülenbacha Latviešu valodas vārdnīca. Rediğēijis, papildinājis, turpinājis J. Endzelīns). I-IV. Riga: Lettisches Bildungsministerium, 1923-1932.

Notes sur l'histoire des diphtongues ie et $u o$ dans les langues baltiques. Bulletin de la Société de Linguistique de Paris 21, 156-174.

Berührungen zwischen den west finnischen und slavischen Sprachen. I. Slavische Lehnwörter in den west finnischen Sprachen. Helsingfors: Druckerei der finnischen Litteraturgesellschaft.

The Germanic loanwords in Proto-Slavic. Amsterdam-New York: Rodopi.

The phonology of Slavic loanwords in Lithuanian. Journal of Baltic Studies 4(2), 127-129.

A prehistory of Slavic. Heidelberg: Winter. 
Skach, Elisabeth. 2010.

Skardžius, Pranas. 1931
Die slavische Monophthongierung $* e j>\bar{\imath}$ im Lichte der Lehnbeziehungen zum Baltischen und Ostseefinnischen. Wiener Slavistisches Jahrbuch 56, 137-140

7, 2-352.

Smoczyński, Wojciech. 2018. Lithuanian etymological dictionary. Berlin: Lang.

Stang, Christian S. 1957. Slavonic accentuation. Oslo: I kommisjon hos H. Aschehoug (W. Nygaard).

Stang, Christian S. 1966. Vergleichende Grammatik der baltischen Sprachen. Oslo-BergenTromsø: Universitetsforlaget.

Vermeer, Willem. 2015. Dabragezas. http://inslav.ru/zalizniak80/congratulations/ Vermeer.pdf

Wiemer, Björn, and Seržant, East Slavic dialectology: achievements and perspectives of areal Ilja A. 2014. linguistics. Ilja A. Seržant and Björn Wiemer (eds.), Contemporary approaches to dialectology: the area of North, Northwest Russian and Belarusian vernaculars (Slavica Bergensia 13). Bergen: John Grieg AS, 11-80.

Young, Steven. 2009. Tone in Latvian borrowings from Old Russian. Thomas Olander and Jenny Helena Larsson (eds.), Stressing the past. Papers on Baltic and Slavic accentology. Amsterdam-New York: Rodopi, 177-192.

Zaliznjak, Andrej A. 1985. Ot praslavjanskoj akcentuacii k russkoj. Moskva: Nauka.

Zaliznjak, Andrej A. 2004. Drevnenovgorodskij dialekt. 2nd edition. Moskva: Jazyki slavjanskoj kul'tury.

Zinkevičius, Zigmas. 1966. Lietuvių dialektologija. Vilnius: Mintis.

Zinkevičius, Zigmas. 1987. Lietuvių kalbos istorija II: Iki pirmųų raštų. Vilnius: Mokslas.

Zinkevičius, Zigmas 1996. The history of the Lithuanian language. Vilnius: Mokslu ir enciklopediju leidybos institutas.

\section{Rick Derksen}

Leiden

r.h.derksen@gmail.com

\section{KOPSAVILKUMS}

\section{Par agrīnajiem slāvu aizguvumiem austrumbaltu valodās}

\section{Rick DERKSEN}

Fonolog̣isko un akcentolog̣isko liecību analīze apstiprina, ka agrīnie aizguvumi no austrumslāvu valodām latviešu valodā kopumā pieder vecākam slānim nekā agrīnie aizguvumi, kas atrodami lietuviešu valodā. Atškirīibas starp skaņu substitūciju latviešu un lietuviešu valodā zināmā mērā var atspogulot variācijas austrumslāvu donorvalodā. Visticamāk, vecākais aizguvumu slānis ir datējams ar laiku pirms austrumbaltu valodu tonālo sistēmu rašanās. 